\title{
Aging effects on consumption risk-sharing channels in European countries ${ }^{* 1}$
}

\author{
Jeongseok Song ${ }^{2}$, Doojin Ryu ${ }^{3}$
}

\begin{abstract}
This study tests the hypothesis that aging affects risk sharing via capital markets, federal governments, and credit markets. We apply the decomposition method to both simulated and European country data. For the simulation, we consider a simple overlapping-generations model and generate data that theoretically fit the model. Empirically, we apply the variance decomposition method using data from Europe. We find some evidence that aging has a significant effect on consumption risk-sharing via the credit market channel, whereas the results for other channels are mixed. With moderate reservations, our empirical results for Europe are consistent with the results derived from the simulated data.
\end{abstract}

Key words: European countries, aging, consumption risk sharing, economic integration, variance decomposition

JEL classification: F15, F36, G20, H7

\section{Introduction}

Rapid aging has recently emerged as a central issue in developed economies (Jianakoplos and Bernasek, 2006). In Europe, the old-age dependency ratio, which is the ratio of the older population to the working population, is projected to double

* Received: 23-01-2018; accepted: 04-12-2018

1 We would like to thank Editor-in-Chief and anonymous referees for their valuable comments. The earlier version of this paper ("Demographic Effects on the Consumption Risk-sharing") has been presented at the 87th Annual Western Economic Association Conference.

2 Professor, School of Economics, Chung-Ang University, 84, Heukseok-ro, Dongjak-gu, Seoul, 06974, Republic of Korea. Scientific affiliation: applied econometrics, international finance, open macroeconomics. Phone: +82 2820 5640.Fax: +82 23280 5582.E-mail: jssong@cau.ac.kr.

3 Professor, College of Economics, Sungkyunkwan University, 25-2, Sungkyunkwan-ro, Jongnogu, Seoul 03063, Republic of Korea. Scientific affiliation: financial economics, corporate social responsibility, fintech, market microstructure. Phone: +82 2760 0429. Fax: +82 27600950. E-mail: sharpjin@skku.edu (correspondingauthor). 
by 2050 . Bellante and Green (2004) find that the elderly hold an increasingly large share of wealth and, thus, are major participants in financial markets. The financial behavior of the elderly has therefore drawn keen attention not only at the individual and household levels but also at the regional and national levels.

We study the effect of population aging on consumption risk-sharing channels across countries. Previous studies regard consumption risk sharing as an arrangement made by risk-averse agents to achieve stable consumption. Risk-averse agents view income changes yielding volatile consumption as a source of consumption risk. Accordingly, such agents are believed to pursue stable consumption through consumption smoothing, making risk aversion a key driver of consumption risk sharing.

Many previous studies use micro-level data to show that risk aversion is related to economic agents' ages. We extend this line of research by focusing on the country rather than the micro level. In a related study, Storesletten et al. (2004) examine the relationship between aging and consumption risk sharing in the United States (US). They use data from the Panel Study of Income Dynamics to calibrate an overlapping-generations model to identify the relationship between aging and consumption risk sharing given income and consumption inequalities. Whereas their study relates aging directly to risk sharing, we investigate the relation between aging and risk-sharing channels.

We consider data from European countries, which are worth investigating in this context for several reasons. First, many European countries have experienced rapid aging for longer than other regions or countries. Second, these European countries provide a good foundation for discussions of international consumption risk sharing because most belong to the European Union (EU), and thus is more financially integrated than other groups of countries or regions are. Representatively, their economic and financial integration, including the use of a common currency, facilitates cross-country ownership and, thus, helps in sharing idiosyncratic income shocks.

In this study, unlike most previous studies, we relate aging to various consumption risk-sharing channels rather than to risk sharing per se. Following Asdrubali et al. (1996), we consider three risk-sharing channels: capital markets, federal governments, and credit markets. Sørensen and Yosha (1998) discuss the notions and roles of risksharing channels in the EU rather than testing the existence of full risk sharing; such tests are performed by Cochrane (1991), Mace (1991), Attanasio and Davis (1996), Hayashi et al. (1996), Dynarski and Gruber (1997), and Crucini (1999).

For our analysis, we modify the regression suggested by Asdrubali et al. (1996) by incorporating the interaction between elderly population growth and income growth into the regression. We simulate the data following a simple overlappinggenerations model and compare the estimation results with simulated data to those using European country data. The results suggest that elderly population growth is 
significantly and positively related to consumption risk sharing via credit markets, whereas the evidence for other channels is mixed.

The paper is structured as follows. Section 2 reviews related literature on consumption risk sharing and aging. Section 3 introduces the analytical methods used. Section 4 presents empirical findings for the European country data and compares the empirical results to those from simulated data. Section 5 discuss the results. Finally, section 6 concludes.

\section{Literature review}

\subsection{Aging and pension systems}

Previous studies on aging mostly focus on longevity risk, which weakens the sustainability of pension systems. Many countries adopt pay-as-you-go pension systems, which heavily depend on the demographic compositions of the young and elderly populations. The relationship between aging and pension systems is extensively documented by Stulz (1981), Canova and Ravn (1996), Bovenberg (2003), Davis and Willen (2000), D'Amato and Galasso (2010), Meyer (2010), Hollanders (2012), Song (2012), de Meijer et al. (2013), Ambrus et al. (2014), Cipriani (2014), Hartley et al. (2014), Poterba (2014), Catalano and Pezzolla (2016), Torben (2014), and Tyrowicz (2016), Dedry et al.(2017), Supan (2017), and Vogel et al. (2017), among others. Cipriani (2014), Tabata (2015), Catalano and Pezzolla (2016), and Tyrowicz (2016) employ the overlapping-generations model for their analyses. D'Amato and Galasso (2010) use the overlapping-generations model to show that aging causes the optimal intergenerational transfer to increase.

In addition, some recent studies focus on aging in Europe, such as those of BörschSupan et al. (2014), Von Wyl and Beck (2014), Catalano and Pezzolla (2016), Cuaresma et al. (2016), and Hamman et al. (2016), among others. Some European countries, especially Western European countries, have developed economies with longer life expectancies than the global average. A report of the EU Social Protection Committee (2012) provides a pension adequacy projection for 2010 2050 and presents the related policy prospects for the EU. Going beyond the policy level, von Wyl and Beck (2014) use an actuary model to examine aging effects on insurance risk adjustments.

Studies also consider the association between aging and pension systems in addressing labor market issues. De La Croix et al. (2013) incorporate aging and pensions into a dynamic general equilibrium model and find that labor market frictions matter more in this case than they do otherwise. Schröder et al. (2016) provide a comprehensive debate on labor market policy for rapid aging in Germany, the United Kingdom, Japan, and the Republic of Korea. Finally, some previous 
studies examine pensions under rapid aging in the macroeconomic context, including those of Kruse (2002), Artige et al. (2014), Verbic (2014), Kolasa and Rubaszek (2016), and Catalán and Magud (2017), among others.

Unlike previous studies, we mainly focus on consumption risk under population aging. Regarding consumption as the ultimate determinant of utility, an individual agent hedges consumption risk by trading financial assets and, thus, demands financial assets. As discussed in Bommier and Rochet (2005), population aging may affect aggregate demand in asset markets because the elderly population may differ from the younger population in terms of risk aversion and preferences for assets.

\subsection{Intergenerational and international risk sharing}

Many previous studies that relate pension systems to longevity shocks utilize intergenerational risk-sharing models. Pensions are not, however, the only financial instrument available to the elderly. Particularly in developed economies, the elderly also participate directly in financial markets. An important function of asset markets is pooling and sharing consumption risk across individual economic units, such as people, regions, and countries. Asdrubali et al. (1996) examine consumption risk sharing across US states via various channels using a variance decomposition approach.

This approach for measuring consumption risk sharing has been extensively applied to various regions and countries. For developed countries, Sorensen and Yosha (1998) find that the part of shocks to gross domestic product (GDP) are smoothed via the fiscal channel, and absorbed by corporate savings. Using statelevel data for Canada and country-level data for the G-7, Crucini (1999) suggests that intranational risk sharing is more significant than international risk sharing. Becker and Hoffman (2006) also compare intranational and international risk sharing for OECD countries, and Kim et al. (2006) apply the same approach to East Asian countries. Song (2015) studies interregional risk sharing under risk aversion heterogeneity using Korean provincial data. Schulhofer-Wohl (2011), Chiappori et al. (2014), and Park and Song (2018) relate risk aversion heterogeneity to consumption risk sharing. Hepp and von Hagen (2012) apply the decomposition method to provincial districts in Germany. Decressin (2002) examines risk sharing within Italy compared with that in the EU and finds that Italy achieves less redistribution via the fiscal channel than that shared among EU member states. Ferrari and Picco (2016) examine the effect of the Euro on financial integration in the EU in view of consumption risk sharing. Park and Song (2009) revisit the variance decomposition approach to examine differences in the degree of consumption risk sharing within the EU, and Song (2011) explores the relationship between consumption risk sharing and income smoothing using European data. 


\subsection{Financial issues relevant to aging}

Additionally, some previous studies, such as those of Wallach and Kogan (1961), Palsson (1996), Wang and Hanna (1997), Ludwig and Winter (2002), Hallahan et al. (2003), Chaulk et al. (2003), Bakshi and Chen (2004), Poterba (2004), Storesletten et al. (2004), Gerrans et al. (2010), and Albert and Duffy (2012), consider the effect of population aging on financial issues, including consumption risk sharing. Palsson (1996), Wang and Hanna (1997), and Storesletten et al. (2007) suggest that aging can play a crucial role in asset markets because it affects risk aversion and, thus, portfolio choice. Palsson (1996) finds that risk aversion increases with age using Swedish household data. On the contrary, Wang and Hanna (1997) show that risk tolerance increases with age using data from the Survey of Consumer Finances in the US. Ludwig and Winter (2002) study the relation between aging and international capital flows and find that capital flows from rapidly aging countries to the rest of the world. Storesletten et al. (2004) examine the relationship between aging and consumption risk sharing and find that income and consumption inequality increase with aging. Their study is similar to ours because it considers consumption risk sharing to be a financial behavior relevant to aging. Our study, however, further examines the effect of aging on consumption risk-sharing channels.

\section{Methodology}

\subsection{Variance decomposition}

We measure the degree of consumption risk-sharing across different regions, based on the methodology of Asdrubali et al. (1996). They measure the fraction of idiosyncratic income shocks that are absorbed through various channels, including capital markets, federal governments, and credit markets. This measure is based on the following variance decomposition:

$$
G D P_{i, t} \equiv \frac{G D P_{i, t}}{G N I_{i, t}} \times \frac{G N I_{i, t}}{G N D I_{i, t}} \times \frac{G N D I_{i, t}}{c_{i, t}} \times C_{i, t}
$$

where $G D P_{i, t}$ represents the GDP of country $i$ in year $t ; G N I_{i, t}$ denotes gross national income (GNI), which equals the sum of $G D P_{i, t}$ and the net foreign factor income of country $i$ in year $t$; and $G N D I_{i, t}$ denotes the gross national disposable income (GNDI), which equals the sum of GNI and federal transfers less federal taxes at the EU commission level. Lastly, $C_{i, t}$ denotes country $i$ 's final consumption in year $t$. Taking the log difference and expectation of this identity, we obtain the following. 


$$
\begin{aligned}
1 & \equiv\left\{\frac{\operatorname{cov}\left(\Delta \log G D P_{i, t}-\Delta \log G N I_{i, t}, \Delta \log G D P_{i, t}\right)}{\operatorname{var}\left(\Delta \log G D P_{i, t}\right)}\right\} \\
& +\left\{\frac{\operatorname{cov}\left(\Delta \log G N I_{i, t}-\Delta \log G N D I_{i, t}, \Delta \log G D P_{i, t}\right)}{\operatorname{var}\left(\Delta \log G D P_{i, t}\right)}\right\} \\
& +\left\{\frac{\operatorname{cov}\left(\Delta \log G N D I_{i, t}-\Delta \log C_{i, t}, \Delta \log G D P_{i, t}\right)}{\operatorname{var}\left(\Delta \log G D P_{i, t}\right)}\right\}+\left\{\frac{\operatorname{cov}\left(\Delta \log C_{i, t}, \Delta \log G D P_{i, t}\right)}{\operatorname{var}\left(\Delta \log G D P_{i, t}\right)}\right\}
\end{aligned}
$$

where $\operatorname{var}(\bullet)$ and $\operatorname{cov}(\bullet)$ denote the variance and covariance operators, respectively. The variance in the income shock, $\Delta \log G D P_{i, t}$, is therefore decomposed into four risk-sharing channel components. For example, the first term corresponds to the ordinary least squares (OLS) estimate of regressing $\Delta \log G D P_{i, t}-\Delta \log G N I_{i, t}$ on $\Delta \log G D P_{i, t}$. Conceptually, the gap between GDP and GNI growth captures the change in net foreign factor income and, thus, represents the response of foreign asset holdings to domestic income shocks. From the perspective of consumption risk sharing, the first term quantifies the income shock absorbed by capital markets. The second term represents consumption shared by federal governments, and the third term measures consumption smoothing via credit markets. Thus, the first three terms on the right-hand side correspond to regressions quantifying these risksharing channels, which we henceforth refer to as risk-sharing regressions. The last term represents the response of the consumption growth rate to income shocks and, thus, reflects unsmoothed consumption risk.

\subsection{Data generation}

Following the literature that we introduce, we assume that time is discrete and infinite. Each individual lives for two periods. We assume that young agents are born at the start of period $t$ and that old agents born in period $t-1$ die at the end of period $t$. For simplicity, we consider only two countries, denoted 1 and 2 . We assume that each young agent in country $i$ at time $t$ is exogenously endowed with $y_{i, t}$ and invests part of her endowed income in the foreign country's asset instead of the domestic asset. Old agents receive random returns from investments made in their youth. For simplicity, the foreign asset supply always satisfies its demand at a fixed price that we set equal to one. Given these assumptions, each agent born at time $t$ chooses his optimal asset investment $a_{i, t}$ and savings $s_{i, t}$ through the following maximization problem:

$$
\begin{array}{ll}
\max & \frac{1}{1-\sigma}\left(c_{i, t}^{y}\right)^{1-\sigma}+\beta E_{t}\left[\frac{1}{1-\sigma}\left(c_{i, t+1}^{o}\right)^{1-\sigma}\right] \\
\text { s.t. } & c_{i, t}^{y}+a_{i, t}+s_{i, t}=(1-\tau) y_{i, t} \\
& c_{i, t+1}^{o}=a_{i, t} r_{i, t+1}+s_{i, t}
\end{array}
$$


This utility function takes the typical constant relative risk aversion form, and $\sigma$, the risk aversion parameter, takes any positive value besides one. Larger values of $\sigma$ indicate greater risk aversion. Once this optimization problem is solved, the resulting investment and savings determine the young agent's consumption at time $t, c_{i, t}^{y}$ and the old agent's consumption at time $t+1, \mathrm{c}_{i, t+1}^{o}$, according to the constraints.

The roles of capital markets, federal governments, and credit markets are considered in the model. The asset investment, $a_{i, t}$, represents the capital market. To easily understand the capital market as a cross-country risk-sharing channel, we assume that agents invest only in foreign assets. Unlike older agents, who own foreign assets, younger agents only have domestic income and, thus, directly face idiosyncratic income risks. $\tau$ indicates the federal government; a positive value represents a tax on the agent, whereas a negative value implies a transfer. To highlight the risk-sharing roles of taxes and transfers, we assume that they only apply to the young generation. Savings, $s_{i, t}$, represent the credit channel across the two countries.

To simulate an overlapping-generations economy, we assume that the time discount factor, $\beta$, equals 0.99 , and the income tax rate, $\tau$, equals 0.5 . For simplicity, we assume that an individual country's income is either 110 in a good state or 40 in a bad state. We assume that countries 1 and 2 exist for 25 periods $(t=1$ to $t=25)$. To incorporate idiosyncratic income shocks, we assume that country 1 is in a good (bad) state if country 2 is in a bad (good) state. We provide more detailed assumptions on the risk aversion parameter in the sequel. We define the parameter for the degree of aging, $v$, as follows. In period 1, we assume that the initial elderly population is 100 in countries 1 and 2 . However, we assume that the young population born in period 1 equals $\left(100^{-v}\right)$ in country 1 but $\left(100^{+v}\right)$ in country 2 . Imposing this assumption repeatedly, the young population born in period $t$ equals $\left(100^{-t v}\right)$ in country 1 and $\left(100^{+t v}\right)$ in country 2 .

By the nature of the overlapping-generations model, country 1's population decreases over time, and country 2's population increases over time. Note, however, that the ratio of elderly to younger people increases in both countries as time passes. ${ }^{4}$ Thus, larger values of $v$ accelerate the speed at which each country ages.

We assume that investments in the risky asset lead to either a higher return, $r_{H}$, of 1.1 , or a lower return, $r_{L}$, of 0.4 in the following period with probability $0.5{ }^{5} \mathrm{We}$ assume that the income tax rate, $\tau$, equals 0.4 because the average personal income tax rate is about 39 percent in the EU.

We denote the ratios of the optimal investment and savings to the disposable endowment as $A$ and $B$, respectively. Thus, the optimal levels of investment and

\footnotetext{
4 The ratio of the elderly to the total population also increases in both countries.

5 All assumed values are chosen to make the simulation results as sensible as possible after much trial and error.
} 
savings equal $A(1-\tau) y_{i, t}$ and $B(1-\tau) y_{i, t}$, respectively. For notational convenience, we define $D$ such that $B=A D$. Combining the first-order conditions with respect to investment $a_{i, t}$ and saving $s_{i, t}$, we obtain

$$
D=\frac{r_{H}-\eta r_{L}}{\eta-1},
$$

where $\eta$ denotes $\left\{\left(r_{H}-1\right) /\left(1-{ }_{r L}\right)\right\}^{1 / \sigma}$. We substitute Equation (4) into either of the first-order conditions with respect to $a_{i, t}$ and $s_{i, t}$ and express $A$ as

$$
A=\frac{1}{\left\{1+D+\left(\frac{2}{\beta}\right)^{1 / \sigma} \frac{\left(r_{H}+D\right)\left(r_{L}+D\right)}{\left[\left(r_{H}+D\right)^{\sigma}+\left(r_{L}+D\right)^{\sigma}\right]^{1 / \sigma}}\right\}}
$$

Here, we can obtain optimal savings from the assumptions $B=A D$ and $s_{i, t}=B(1-\tau) y_{i, t}$.

To simulate aggregate GDP, we inflate the exogenous endowment, $y_{i, t}$, by the young population, $N_{i, t}^{y}$. Then, country $i$ 's GDP is assumed to equal $N_{i, t}^{y} y_{i, t}$, following Asdrubali et al. (1996), who regard GDP as exogenous. For GNI, we add GDP to simulated factor income. In the simulation, factor income equals the product of the elderly population, $N_{i, t}^{o}$ and $r_{j, t} a_{i, t-1},(j \neq i)$. Next, we simulate GNDI by calculating $(1-\tau) y_{i, t} N_{i, t}^{y}+r_{j} a_{i, t} N_{i, t}^{o}$. Finally, we simulate aggregate consumption by multiplying $c_{i, t}^{y}$ and $c_{i, t}^{o}$ by the young and old populations, $N_{i, t}^{y}$ and $N_{i, t}^{o}$, respectively. Thus, aggregate consumption equals $N_{i, t}^{y} c_{i, t}^{y}+N_{i, t}^{o} c_{i, t}^{o}$ in the simulated economy. Note that $N_{i, t}^{y}$ and $N_{i, t}^{o}$ are defined by the assumptions regarding $v_{i}$ and country $i$ 's initial population.

Using the simulated aggregate data, we discuss the consumption risk-sharing channels. For capital markets, the associated regression setup is

$$
\Delta \log \left(g d p_{i, t}\right)-\Delta \log \left(g n i_{i, t}\right)=\alpha_{t}+\beta_{k} \Delta \log \left(g d p_{i, t}\right)+\varepsilon_{k, i, t}
$$

where $g d p_{i, t}$ and $g n i_{i, t}$ denote the per capita levels of GDP and GNI simulated by the overlapping-generations model. According to Asdrubali et al. (1996), the dependent variable in Equation (6) conceptually reflects the growth rate of net factor income outflows. Thus, a positive estimate of $\beta_{k}$ implies that an increase in country $i$ 's GDP growth rate is accompanied by an increase in the growth rate of net factor income outflows, which, in turn, is likely to reduce the country's consumption growth rate. Thus, the direct effect of a positive income shock on consumption is likely stabilized by adjustments to net factor income. At the country level, the production factor is mostly traded via the international capital market rather than the labor market.

By the definitions of GDP and GNI in the simulation, we obtain

$$
\frac{g d p_{i, t}}{g n i_{i, t}}=\frac{N_{i, t}^{y} y_{i, t}}{N_{i, t}^{y} y_{i, t}+N_{i, t}^{o} r_{j} a_{i, t}}=\frac{1}{1+\mu r_{j} A(1-\tau) \nabla_{i, t}}
$$


The first equality in Equation (7) holds because the ratio of GDP to GNI in per capita terms is equivalent to that in levels. The second equality results from dividing the denominator and the numerator of $N_{i, t}^{y} y_{i, t} /\left(N_{i, t}^{y} y_{i, t}+N_{i, t}^{o} r_{j} a_{i, t}\right)$ by $N_{i, t}^{y} y_{i, t}$. Then, $\mu$ denotes the ratio of the elderly population $N_{i, t}^{o}$ to the young population $N_{i, t}^{y}$. Furthermore, $\nabla_{i, t}$ represents $\left(y_{i, t-1} / y_{i, t}\right)$. Using the proper notation, $g d p_{i, t}$ equals $y_{i, t} /(1$ $+\mu)$, and, thus, $\log \left(g d p_{i, t}\right)$ equals $\log \left(y_{i, t}\right)-\log (1+\mu)$.

The simulated term $\left(g d p_{i, t} / g n i_{i, t}\right)$ on the left side of Equation (7) is closely related to the dependent variable in Equation $(6), \Delta \log \left(g d p_{i, t}\right)-\Delta \log \left(g n i_{i, t}\right){ }^{6}$ Furthermore, note that the ratio of $G D P_{i, t}$ to $G N I_{i, t}$ equals the ratio of per capita GDP to per capita GNI. We can also express per capita GDP as $y_{i, l} /(1+\mu)$, recalling that $\mu=\left(N_{i, t}^{o} / N_{i, t}^{y}\right)$. In sum, the dependent and independent variables in Equation (6) both include $\mu$, the relative ratio of the elderly to the young. Thus, $\mu$ is inversely related to per capita GDP in the same way that it is related to $\left(g d p_{i, t} / g n i_{i, t}\right)$ in Equation (7). This property motivates our examination of the aging effect on $\beta_{k}$ in Equation (6) for the capital market channel.

The analogous regression setup for the federal government is

$$
\Delta \log \left(g n i_{i, t}\right)-\Delta \log \left(g n d i_{i, t}\right)=\alpha_{t}+\beta_{f} \Delta \log \left(g d p_{i, t}\right)+\varepsilon_{f, i, t}
$$

where $g n d i_{i, t}$ denotes per capita GNDI simulated in the model. The dependent variable in Equation (8), $\Delta \log \left(g n i_{i, t}\right)-\Delta \log \left(g n d i_{i, t}\right)$, can be attributed to net tax, which is imposed across all countries within a federation. Higher taxes are levied on countries with positive income shocks, and more transfers are allocated to countries with negative shocks. Thus, a positive estimate of $\beta_{f}$ in Equation (8) implies that the federal government plays a role in consumption risk sharing. By the definitions of GNI and GNDI, we express the simulated term $\left(g n i_{i, t} / g n d i_{i, t}\right)$ as

$$
\frac{g n i_{i, t}}{g n d i_{i, t}}=\frac{1+\mu r_{j} A(1-\tau) \nabla_{i, t}}{(1-\tau)\left\{1+\mu r_{j} A \nabla_{i, t}\right\}}
$$

Note that the values of $\mu$ in the denominator and numerator of Equation (9) do not cancel each other out. Thus, the ratio of the elderly to the young affects the magnitude of $\left(g n i_{i, t} / g n d i_{i, t}\right)$. To determine the effect of $\mu$ on $\left(g n i_{i, t} / g n d i_{i, t}\right)$, we differentiate Equation (9) with respect to $\mu$. The resulting expression is negative:

$$
\frac{d}{d \mu}\left(\frac{g n i_{i, t}}{g n d i_{i, t}}\right)=\frac{\gamma_{j} A \nabla_{i, t}}{1+\mu \gamma_{j} A \nabla_{i, t}}\left\{1-\frac{1+\mu \gamma_{j} A(1-\tau)}{1+\mu \gamma_{j} A(1-\tau)-\tau}\right\}<0 .
$$

The term within large brackets on the right-hand side of Equation (10) is negative, assuming a tax rate $\tau$ between zero and one. Thus, Equation (10) also implies that an

\footnotetext{
$\overline{{ }^{6} \text { We also consider }}$ the log differenced form.
} 
increase in $\mu$ reduces $\left(g n i_{i, t} / g n d i_{i, t}\right)$. Recalling that $g d p_{i, t}$ equals $1 /(1+\mu) y_{i, t}$, a larger $\mu$ implies that both $\left(g n i_{i, t} / g n d i_{i, t}\right)$ and $g d p_{i, t}$ decrease. This property motivates our examination of the effect of aging on $\beta_{f}$ in Equation (8) for the federal government channel.

Lastly, the regression setup for the credit market channel is

$$
\Delta \log \left(g n d i_{i, t}\right)-\Delta \log \left(c_{i, t}\right)=\alpha_{t}+\beta_{c} \Delta \log \left(g d p_{i, t}\right)+\varepsilon_{c, i, t} .
$$

where $c_{i, t}$ denotes simulated per capita consumption. As for other channels, the dependent variable, $\Delta \log \left(g n d i_{i, t}\right)-\Delta \log \left(c_{i, t}\right)$, represents the difference between the simulated growth rates of per capita GNDI and final consumption, which also represents each country's savings. In particular, Asdrubali and Kim (2008a, 2008b) extend Equation (11) to measure both intertemporal smoothing and cross-sectional sharing in a unified framework. Asdrubali and Kim (2004) suggest using vector autoregression to measure dynamic risk sharing for different channels.

If country i's GNDI grows faster than its final consumption owing to positive economic shocks, then it can save and lend more via the credit market. The opposite holds for negative shocks. Thus, the loan and credit market can be regarded as a consumption stabilizing mechanism. From the simulation definitions of GNDI and final consumption, we obtain

$$
\frac{g n d i_{i, t}}{c_{i, t}}=\frac{1+\mu r_{j} A \nabla_{i, t}}{(1-A-B)+\mu\left(r_{j} A+B\right) \nabla_{i, t}} .
$$

Recall that $B$ equals $s_{i, t} /\left\{(1-\tau) y_{i, t}\right\}$. Equation (12) seems to be more complicated than its counterparts for other channels. To consider the possible effect of $\mu$ on (gndi $i_{i, l} / \mathbf{c}_{i, t}$ ), we differentiate (12) with respect to $\mu$ :

$$
\frac{d}{d \mu}\left(\frac{g n d i_{i, t}}{c_{i, t}}\right)=\frac{r_{j} A \nabla_{i, t}}{(1-A-B)+\mu\left(r_{j} A+B\right) \nabla_{i, t}}\left\{1-\frac{\left(1+\mu r_{j} A \nabla_{i, t}\right)\left(r_{j} A+B\right)}{\left[(1-A-B)+\mu\left(r_{j} A+B\right) \nabla_{i, t}\right] r_{j} A}\right\} .
$$

Unlike in the other channels, the sign of Equation (13) is not determined unless further conditions are imposed. Specifically, the sign of the term in large brackets on the right-hand side of Equation (13) is ambiguous. Thus, we cannot decisively clarify the relation between $\mu$ and ( $\left(\right.$ gndi $\left._{i, t} / c_{i, t}\right)$. Nevertheless, $\mu$ is included in Equation (13) and provides motivation for empirically investigating the aging effect on $\beta_{c}$ in Equation (11).

Given the interaction between income and elderly population growth, an analytical interpretation of the simulated data is not simple, as the interaction term is absent. Thus, we rely directly on the numerical results and provide t-statistics for the estimates of the interaction term included in the modified regression: 
$z_{i, t}=\alpha_{t}+\beta \Delta \log \left(G D P_{i, t}\right)+\gamma \Delta \log \left(G D P_{i, t}\right) \Delta \log \left(O L D_{i, t}\right)+\delta \Delta \log \left(O L D_{i, t}\right)+\varepsilon_{i, t}$,

where $\Delta \log \left(O L D_{i, t}\right)$ denotes the growth rate of the elderly population. The generic variable $z_{i, t}$ represents $\Delta \log \left(G D P_{i, t}\right)-\Delta \log \left(G N I_{i, t}\right), \Delta \log \left(G N I_{i, t}\right)-\Delta \log \left(G N D I_{i, t}\right)$ , or $\Delta \log \left(G N D I_{i, t}\right)-\Delta \log \left(C_{i, t}\right)$, which correspond to the capital market, federal government, and credit market channels, respectively. Including an interaction term in Equation (14) renders it difficult to interpret the associated coefficient because the estimate is not easily translated into a share of income fluctuations absorbed by a given channel. Despite this difficulty interpreting the interaction term, Mélitz and Zumer (1999) and Sørensen et al. (2007) extend the simple OLS regression with income shocks to regressions with additional regressors. Conventionally interpreting the interaction terms, a significant estimate of $\gamma$ implies that elderly population growth, $\triangle \log \left(O L D_{i, t}\right)$, can influence the effect of income growth, $\Delta \log \left(G D P_{i, t}\right)$, on the dependent variable, $z_{i, t}$. We run these regressions for various values of the aging and risk aversion parameters.

\section{Empirical data and analysis}

\subsection{Simulated data regression}

Following the simulation described in section 3, we generate artificial panel data for GDP, GNI, GNDI, and consumption in per capita terms. We assume that two countries exist for 25 periods. To consider many cases, we assume that the risk aversion parameter ranges from 1.3 to 5.1 and aging parameter ranges from 0.2 to 3.6. We set the parameter grid equal to 0.2 to yield 340 data sets.

Using the simulated data, we run the risk-sharing regression in Equation (14) for the capital market, federal government, and credit market channels. We then calculate the t-statistics of the estimated coefficients on the interaction between income shocks and elderly population growth. We present t-statistics rather than the associated estimates because the scale of these estimates is extremely unstable across the parameter values. We do report the estimated coefficients on the income shock variable, as they fall into a reasonable range, as in previous studies.

Figure 1 indicates that the t-statistics for the interaction terms in the risk-sharing regressions for capital markets are mostly below 1.5. However, the t-statistics sharply increase with the aging parameter as the aging parameter approaches its maximum, 3.4. The t-statistics only increase along the risk aversion parameter axis for extremely large values of the aging parameter. Overall, elderly population growth exhibits no significant effect on consumption risk sharing via the capital channel, although the interaction effect is present for limited large values of the aging parameter. 
Figure 1: Interaction term t-statistics: Capital market

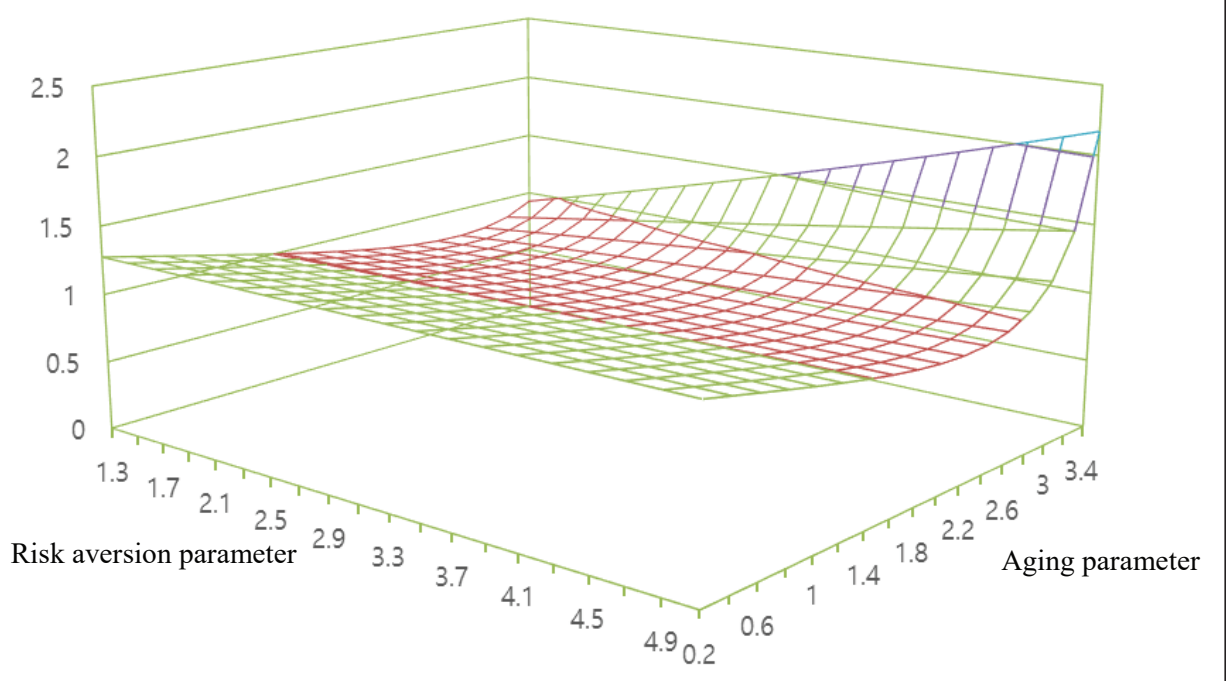

Source: Authors' calculation

Figure 2 shows that the t-statistics for the interaction term using simulated data in the regressions for the federal government channel are negative and close to zero. In fact, the t-statistics appear rather stable along the aging parameter axis, although they increase somewhat along the risk aversion parameter axis. Thus, aging does not explain consumption risk sharing via the federal government.

Figure 2: Interaction term t-statistics: Federal government

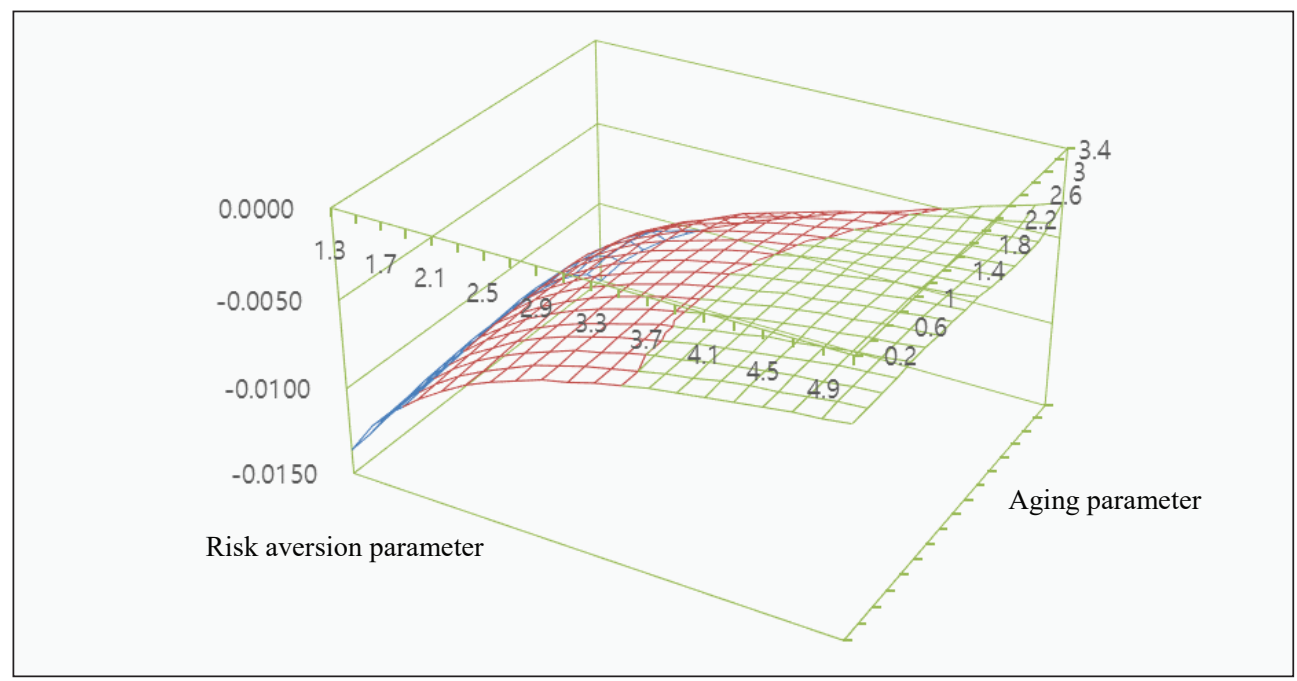

Source: Authors' calculation 
Figure 3 shows that the t-statistics for the interaction term using simulated data in the regressions for the credit market channel are positive and increasing as the aging parameter decreases. Along the risk aversion parameter axis, the t-statistics appear stable. Consequently, elderly population growth can be said to affect consumption risk sharing through the credit market. Thus, the interaction between elderly population growth and credit markets is relatively more important than that for other channels.

Figure 3: Interaction term t-statistics: Credit market

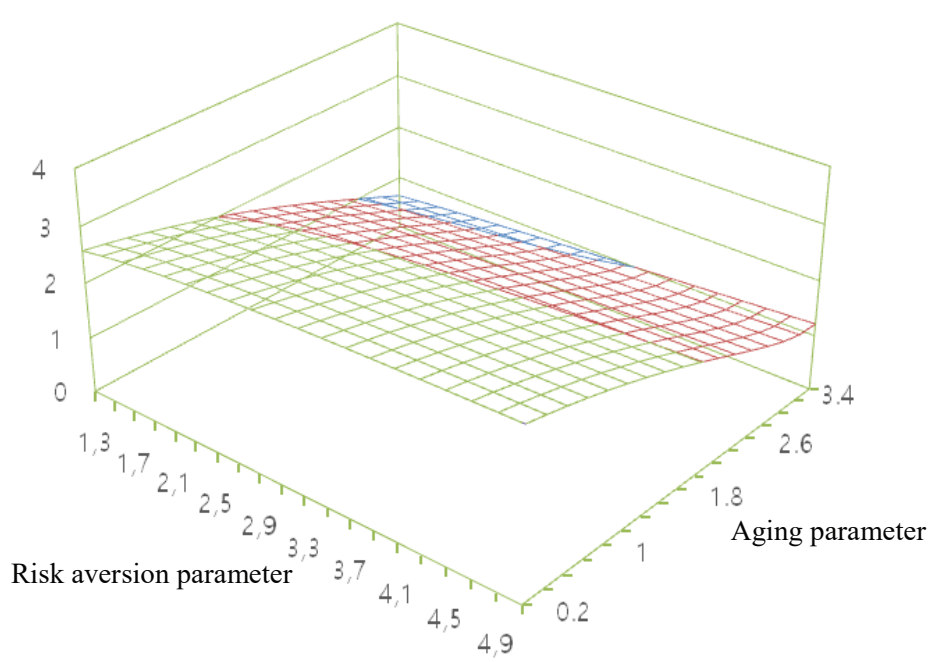

Source: Authors' calculation

Following Asdrubali et al. (1996), we consider income shock estimates that quantify the degree of risk sharing achieved by each channel for comparison with previous studies. As a benchmark, we first run the simple regression without an interaction term or the elderly population growth rate. Table 1 presents the results.

Recall that the aging parameter measures the growth rate of the elderly population ratio. The second through fifth columns provide averages of the estimates of $\beta_{k}, \beta_{c}$, $\beta_{f}$, and $\beta_{u}$, respectively, over discrete, equally spaced values of the risk aversion parameter, $\sigma$, from 1.3 and 5.1. The sum of these estimates equals one for all values of the aging parameter, as observed by Asdrubali et al. (1996). 
Table 1: Risk-sharing estimates: regressions with no interaction term

\begin{tabular}{|c|c|c|c|c|c|}
\hline $\begin{array}{c}\nu \\
\begin{array}{c}\text { Aging } \\
\text { parameter }\end{array}\end{array}$ & $\begin{array}{c}\text { Capital } \\
\text { market } \\
\left(\beta_{k}\right)\end{array}$ & $\begin{array}{c}\text { Credit } \\
\text { market } \\
\left(\beta_{c}\right)\end{array}$ & $\begin{array}{c}\text { Federal } \\
\text { government } \\
\left(\beta_{f}\right)\end{array}$ & $\begin{array}{c}\text { Unsmoothed } \\
\text { risk } \\
\left(\beta_{u}\right)\end{array}$ & $\begin{array}{c}\text { Sum } \\
\left(\beta_{k}+\beta_{c}+\beta_{f}+\beta_{u}\right)\end{array}$ \\
\hline 0.9 & 0.0223 & 0.1254 & 0.7009 & 0.1514 & 1.0000 \\
\hline 1.2 & 0.0223 & 0.1258 & 0.7009 & 0.1510 & 1.0000 \\
\hline 1.5 & 0.0223 & 0.1263 & 0.7009 & 0.1505 & 1.0000 \\
\hline 1.8 & 0.0224 & 0.1269 & 0.7008 & 0.1499 & 1.0000 \\
\hline 2.1 & 0.0225 & 0.1278 & 0.7007 & 0.1490 & 1.0000 \\
\hline 2.4 & 0.0225 & 0.1289 & 0.7006 & 0.1479 & 1.0000 \\
\hline 2.7 & 0.0226 & 0.1305 & 0.7004 & 0.1465 & 1.0000 \\
\hline 3 & 0.0228 & 0.1326 & 0.6998 & 0.1448 & 1.0000 \\
\hline 3.3 & 0.0230 & 0.1360 & 0.6982 & 0.1429 & 1.0000 \\
\hline 3.6 & 0.0236 & 0.1437 & 0.6909 & 0.1419 & 1.0000 \\
\hline
\end{tabular}

Source: Authors' calculation

Although our main focus is the effect of the aging parameter on estimates of risk sharing, to more easily interpret the results in Table 1, we discuss the relation between the aging parameter and the dependent variables corresponding to the estimated $\beta_{k}, \beta_{c}, \beta_{f}$, and $\beta_{u}$. Simple OLS estimates can be viewed as $\operatorname{cov}(x, y) / \operatorname{var}(x)$, where $\operatorname{cov}(x, y)$ represents the covariance of $x$ and $y$ and $\operatorname{var}(x)$ represents the variance of $x$. When $x$ and $y$ are log-differenced, their expected values equal zero, as is true for many macroeconomic time series. Thus, we can express $\operatorname{cov}(x, y) / \operatorname{var}(x)$ as $E(x y) / E\left(x^{2}\right)$, where $x$ denotes the same regressor for all the risk-sharing regressions and $y$ represents the variables corresponding to the four different regressions. To show differences in the effect of aging parameter on $E(x y) / E\left(x^{2}\right)$ across different regressions, we momentarily exclude $x$ and concentrate on $y$ 's response to an increase in the aging parameter because, as $y$ increases, the magnitude of $E(x y) /$ $E\left(x^{2}\right)$ tends to increase.

In Table 1, as the aging parameter increases, the average estimates for capital and credit markets increase. The dependent variable associated with capital markets, $y$, mainly consists of net foreign factor income. Our simulation assumes that young agents in each country buy only foreign assets rather than domestic assets. Elderly agents are assumed to realize their foreign asset returns as foreign factor income and spend it. Thus, an increasing elderly ratio increases factor income from abroad. The increased foreign factor income implies that the role of capital markets in smoothing idiosyncratic income shocks increases when the elderly population ratio increases. By definition, a larger aging parameter implies faster increases in the elderly population ratio. The estimates for $\beta_{k}$ are therefore consistent with our simulation model. 
The dependent variable, $y$, associated with credit markets is the gap between per capita consumption and per capita GNDI. This gap absorbs income shocks via credit markets. The simulation defines younger agents' consumption as GDP minus taxes and investment and savings. The elderly generation's consumption equals their foreign investment returns and savings. GNDI equals GDP minus tax plus the elderly generation's realized foreign investment returns.

Consequently, the difference between GNDI and total consumption equals the elderly generation's savings use minus the younger generation's savings and foreign asset investments. Then, an increase in the elderly population ratio increases the positive contribution to the gap between GNDI and consumption and reduces the negative contribution. Thus, faster aging further expands the gap between per capita GNDI and per capita consumption, which helps cushion income shocks via credit markets. Thus, risk sharing via credit markets increases under faster aging, consistent with the estimates for $\beta_{c}$ in the third column of Table 1.

Unlike the estimates for $\beta_{k}$ and $\beta_{c}$, the estimate for $\beta_{f}$ decreases as the aging parameter increases. This estimate quantifies the risk sharing achieved by the federal government through the gap between per capita GNI and per capita GNDI. Conceptually, this gap corresponds to taxes imposed only on GDP. In our model, GDP is exogenously endowed only to young agents. Therefore, an increasing elderly population ratio reduces the taxed part of GDP and, thus, reduces the gap between per capita GNI and per capita GNDI. Thus, as the aging parameter increases, the estimated risk sharing via the federal government shrinks. This prediction is consistent with the fourth column of Table 1 .

Lastly, we consider the remaining unsmoothed risk, $\beta_{u}$, which measures the direct impact of income shocks on consumption. Note that the income shock equals the log-differenced GDP. To simplify the discussion, suppose that the entire population only lives when they are young such that nobody makes savings and investments. Moreover, assume that no tax is levied on GDP. In this extreme situation, consumption is identical to GDP, and, thus, the estimated $\beta_{u}$ should equal one. All else equal, suppose that the elderly population begins to increase. Then, people begin to save and invest, and consumption increasingly differs from GDP. Then, the estimated $\beta_{u}$ begins to fall below one. Thus, the estimated $\beta_{u}$ decreases more when the aging parameter increases. This supposition is consistent with the results in the fifth column.

Table 2 presents the estimated $\beta_{k}, \beta_{c}, \beta_{f}$, and $\beta_{u}$ when all relevant regressions include the interaction between income shock and old population growth as a regressor. Again, we note that the sum of $\beta_{k}, \beta_{c}, \beta_{f}$, and $\beta_{u}$ still equals one when the interaction term is included. Each of the four estimates exhibits similar patterns with respect to the aging parameter. 
Table 2: Risk-sharing estimates: regressions with the interaction term

\begin{tabular}{|c|c|c|c|c|c|}
\hline $\begin{array}{c}\nu \\
\text { Aging } \\
\text { parameter }\end{array}$ & $\begin{array}{c}\text { Capital } \\
\text { market } \\
\left(\beta_{k}\right)\end{array}$ & $\begin{array}{c}\text { Credit } \\
\text { market } \\
\left(\beta_{c}\right)\end{array}$ & $\begin{array}{c}\text { Federal } \\
\text { government } \\
\left(\beta_{f}\right)\end{array}$ & $\begin{array}{c}\text { Unsmoothed } \\
\text { risk } \\
\left(\beta_{u}\right)\end{array}$ & $\begin{array}{c}\text { Sum } \\
\left(\beta_{k}+\beta_{c}+\beta_{f}+\beta_{u}\right)\end{array}$ \\
\hline 0.9 & 0.0157 & 0.0778 & 0.7037 & 0.2028 & 1.0000 \\
\hline 1.2 & 0.0178 & 0.1106 & 0.7029 & 0.1686 & 0.9999 \\
\hline 1.5 & 0.0191 & 0.1294 & 0.7024 & 0.1491 & 1.0000 \\
\hline 1.8 & 0.0200 & 0.1406 & 0.7020 & 0.1373 & 0.9999 \\
\hline 2.1 & 0.0206 & 0.1473 & 0.7017 & 0.1303 & 0.9998 \\
\hline 2.4 & 0.0210 & 0.1507 & 0.7014 & 0.1266 & 0.9996 \\
\hline 2.7 & 0.0214 & 0.1518 & 0.7010 & 0.1252 & 0.9993 \\
\hline 3 & 0.0216 & 0.1511 & 0.7005 & 0.1255 & 0.9988 \\
\hline 3.3 & 0.0218 & 0.1490 & 0.6995 & 0.1270 & 0.9973 \\
\hline 3.6 & 0.0218 & 0.1451 & 0.6955 & 0.1287 & 0.9911 \\
\hline
\end{tabular}

Source: Authors' calculation

For easier comparison, Figures 4-7 graph the estimates in Tables 1 and 2. In Figure 4 , the red line illustrates the $\beta_{k}$ estimates for the regressions with an interaction term, and the blue line illustrates those for the regressions without an interaction term. Both lines are upward sloping, implying that the $\beta_{k}$ estimates increase as the aging parameter increases. Furthermore, the estimates are smaller when the interaction term is included. Thus, the risk-sharing estimates are less significant when we incorporate the aging effect. Risk sharing via capital markets therefore partially originates from the aging factor. However, the gap between the two estimates lessens as the aging parameter increases.

Figure 4: Estimated $\beta_{k}$ : Capital market

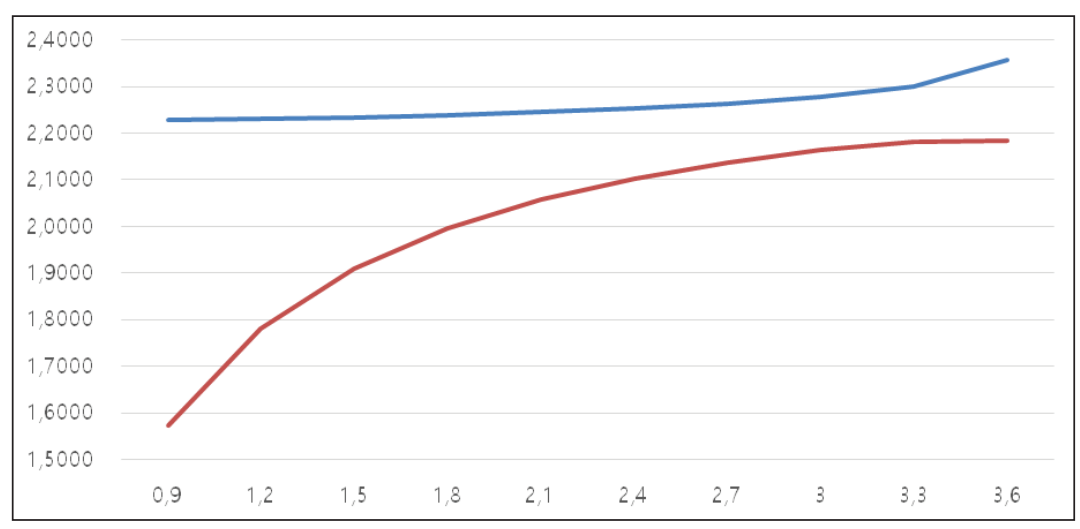

Note: The horizontal axis represents the aging parameter, and the vertical axis represents the $\beta_{k}$ estimates as percent.

Source: Authors' calculation 
Figure 5 shows the same estimates for $\beta_{c}$. According to Figure 5 , the $\beta_{c}$ estimates increase when the aging parameter is less than 2.7 but slightly decrease beyond that value. The estimates associated with the interaction term vary more than those without the interaction term do.

Figure 5: Estimated $\beta_{c}$ : Credit market

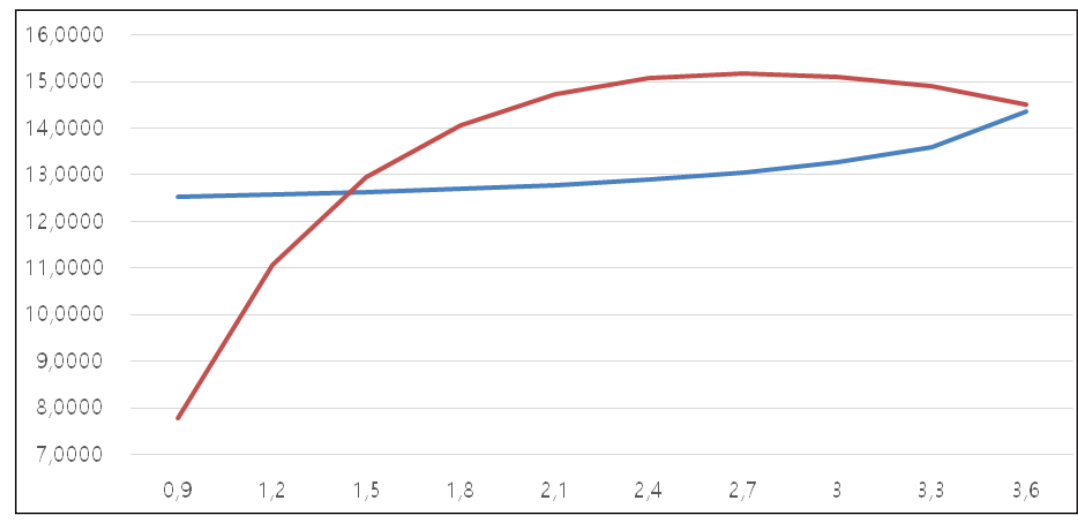

Note: The horizontal axis represents the aging parameter, and the vertical axis represents the $\beta_{c}$ estimates as percent.

Source: Authors' calculation

Figure 6 shows the same estimates for $\beta_{f}$. The two lines are more similar than in the capital market and credit market cases. Moreover, the estimates involving the interaction term are larger than those without the interaction term.

Figure 6: Estimated $\beta_{f}$ : Federal government

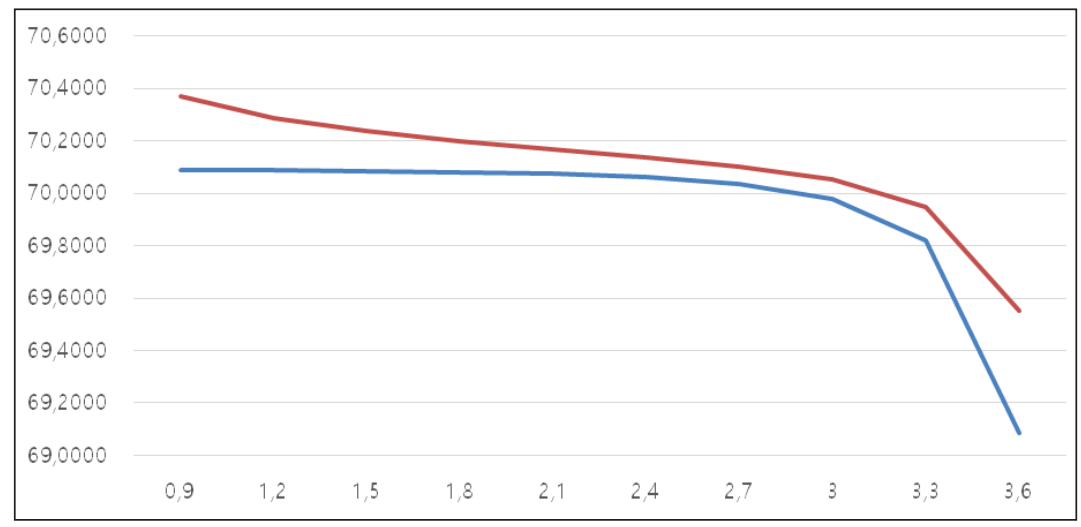

Note: The horizontal axis represents the aging parameter, and the vertical axis represents the $\beta_{f}$ estimates as percent.

Source: Authors' calculation 
Figure 7: Estimated $\beta_{u}$ : Unsmoothed risk

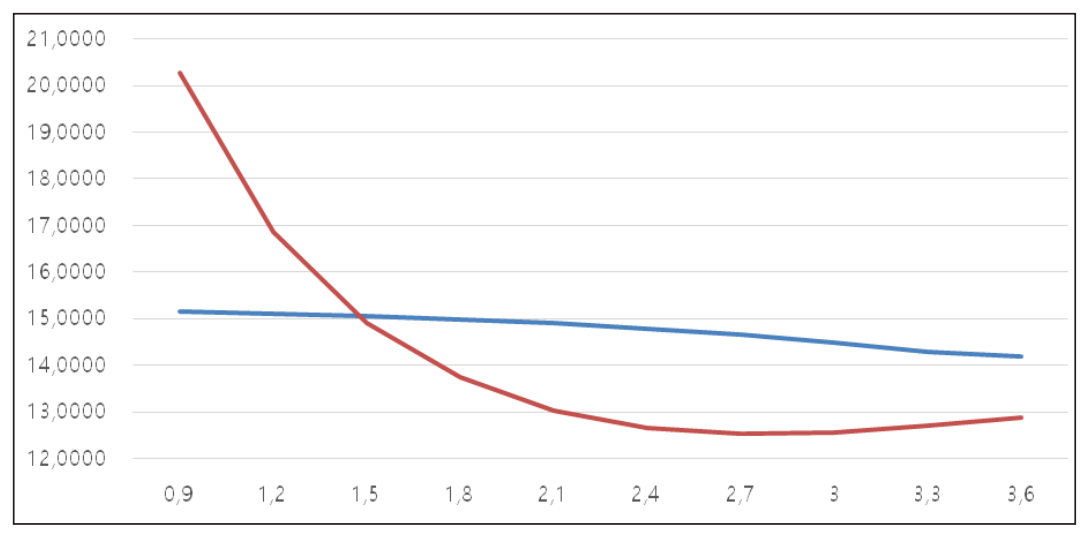

Note: The horizontal axis represents the aging parameter, and the vertical axis represents the $\beta_{u}$ estimates as percent.

Source: Authors' calculation

Finally, Figure 7 shows the same estimates for $\beta_{u}$. As in Figure 5, the $\beta_{u}$ estimates vary more when the associated regression involves the interaction term than when it does not.

\subsection{Sample data construction}

We use country-level population data from the EUROSTAT website from 2000 to 2012. We regard the population over 65 as the elderly population henceforth unless otherwise mentioned. The European countries include Austria, Belgium, Bulgaria, Croatia, Cyprus, Czech Republic, Denmark, Estonia, Finland, France, Germany, Greece, Hungary, Iceland, Ireland, Italy, Latvia, Lithuania, Luxembourg, Netherlands, Norway, Poland, Portugal, Romania, Slovakia, Slovenia, Spain, Sweden, Switzerland, and the United Kingdom. We use the GDP, GNI, GNDI, and final household consumptions for these countries.

\subsection{Panel regression and estimation results}

To examine the interaction between income growth and consumption risk-sharing channels, we run the panel regression in Equation (14) using the European data. ${ }^{7}$ In Table 3, we present the estimation results for the entire sample and compare them to those using simulated data. We use lowercase letters for the relevant variables to distinguish them from the simulated data.

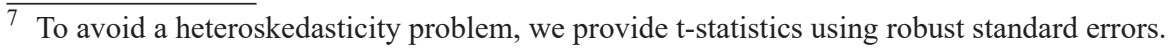


Table 3: Full sample estimation results

\begin{tabular}{|l|c|c|c|}
\hline & $\Delta \log \left(g d p_{i, t}\right)$ & $\Delta \log \left(g d p_{i, t}\right) \Delta \log \left(\right.$ old $\left._{i, t}\right)$ & $\Delta \log \left(\right.$ old $\left._{i, t}\right)$ \\
\hline \multirow{2}{*}{ Capital market } & $0.08^{* *}$ & $-9.45^{* * *}$ & 0.22 \\
& $(2.04)$ & $(-2.63)$ & $(1.63)$ \\
\hline \multirow{2}{*}{ Federal government } & 0.01 & 0.23 & -0.08 \\
& $(0.39)$ & $(0.27)$ & $(-1.14)$ \\
\hline \multirow{2}{*}{ Credit market } & $-0.09^{*}$ & $10.40^{* * *}$ & -0.21 \\
& $(-1.64)$ & $(3.06)$ & $(-1.29)$ \\
\hline
\end{tabular}

Note: $* * *, * *$, and $*$ indicate statistical significance at the $1 \%, 5 \%$, and $10 \%$ levels, respectively. Source: Authors' calculations

For the capital market, the estimate for income growth is positive and significant at the $5 \%$ level. The estimate is approximately 0.08 , implying that the capital market absorbs about $8 \%$ of income shocks. The estimate for the interaction term for this channel is negative and significant at the $1 \%$ level, which is inconsistent with our simulation results in Figure 1. The elderly population growth rate therefore reduces the consumption risk-sharing effect via this channel. We find no significant effects for the federal government channel using the full sample.

For the credit market, the estimate for income growth is negative and significant at the $10 \%$ level. Thus, consumption risk dis-smoothing occurs via the credit channel. In the subsequent analysis, we repeatedly find a negative and significant estimate for income growth for this channel.

As we assume various values for the aging parameter in the simulation, the degree of aging can differ across different real economies. We divide the sample countries into fast-aging, moderate-aging, and slow-aging groups based on the sample average growth rate of the elderly population. The fast-aging countries, ordered by this growth rate, are Italy, Germany, Greece, Sweden, Portugal, Bulgaria, Belgium, Croatia, and Latvia. The slow-aging countries are Lithuania, Norway, Slovakia, Estonia, Hungary, and Romania, The rest of the sample countries belongs to the moderate aging group.

Tables 4-6 present the estimation results for these three subsamples. Table 4 shows that, for the capital market, the $\Delta \log \left(g d p_{i, t}\right)$ estimates are similar to those for the full sample. However, the estimates for $\Delta \log \left(g d p_{i, t}\right) \Delta \log \left(\operatorname{old}_{i, t}\right)$ are significant only for fast-aging countries; they are not significant for other two subsamples. Consistent with the results for the full sample, the estimates for elderly population growth, $\Delta \log \left(\operatorname{old}_{i, t}\right)$, are not significant for any of the subsamples. 
Table 4: Capital market: Subsample analysis

\begin{tabular}{|l|c|c|c|}
\hline & $\Delta \log \left(g d p_{i, t}\right)$ & $\Delta \log \left(g d p_{i, t}\right) \Delta \log \left(\operatorname{old}_{i, t}\right)$ & $\Delta \log \left(\operatorname{old}_{i, t}\right)$ \\
\hline \multirow{2}{*}{ Slow aging } & $0.07^{* *}$ & -3.13 & -0.06 \\
& $(2.22)$ & $(-1.32)$ & $(-0.26)$ \\
\hline \multirow{2}{*}{ Moderate aging } & $0.09^{*}$ & -4.72 & 0.14 \\
& $(1.71)$ & $(-1.33)$ & $(0.63)$ \\
\hline \multirow{2}{*}{ Fast aging } & $0.15^{* * *}$ & $-4.96^{* *}$ & 0.03 \\
& $(3.90)$ & $(-2.33)$ & $(0.17)$ \\
\hline
\end{tabular}

Note: $* * *, * *$, and $*$ indicate statistical significance at the $1 \%, 5 \%$, and $10 \%$ levels, respectively. Source: Authors' calculations

For the federal government channel, the subsample results in Table 5 are quite different from those in Table 3. The estimates for $\Delta \log \left(g d p_{i, t}\right)$ are positive and significant for all three groups, whereas they are not significant for the full sample. The interaction term estimates are not stable across the groups. Finally, the estimate for $\Delta \log \left(\operatorname{old}_{i, t}\right)$ is negative and significant for the slow-aging countries. The latter result differs from that for the full sample.

Table 5: Federal government: Subsample analysis

\begin{tabular}{|l|c|c|c|}
\hline & $\Delta \log \left(g d p_{i, t}\right)$ & $\Delta \log \left(g d p_{i, t}\right) \Delta \log \left(\operatorname{old}_{i, t}\right)$ & $\Delta \log \left(\operatorname{old}_{i, t}\right)$ \\
\hline \multirow{2}{*}{ Slow aging } & $0.05^{* * *}$ & $3.12^{* *}$ & $-0.29^{* *}$ \\
& $(2.74)$ & $(2.25)$ & $(-2.20)$ \\
\hline \multirow{2}{*}{ Moderate aging } & $0.03^{* * *}$ & $-1.54^{* *}$ & 0.07 \\
\hline \multirow{2}{*}{ Fast aging } & $(3.09)$ & $(-2.22)$ & $(1.53)$ \\
\hline
\end{tabular}

Note: $* * *, * *$, and $*$ indicate statistical significance at the $1 \%, 5 \%$, and $10 \%$ levels, respectively. Source: Authors' calculations

As shown in Table 6, the estimation results for the credit market are stable across the three groups. The estimates for $\Delta \log \left(g d p_{i, t}\right)$ are negative and significant for all three groups. This finding is similar to that for the full sample and is consistent with the results using simulated data. In particular, as in Table 3 , the coefficient estimates for the interaction term are positive and significant for all three groups. 
Jeongseok Song, Doojin Ryu • Aging effects on consumption risk-sharing channels...

Table 6: Credit market: Subsample analysis

\begin{tabular}{|l|c|c|c|}
\hline & $\Delta \log \left(g d p_{i, t}\right)$ & $\Delta \log \left(g d p_{i, t}\right) \Delta \log \left(\operatorname{old}_{i, t}\right)$ & $\Delta \log \left(\right.$ old $\left._{i, t}\right)$ \\
\hline \multirow{2}{*}{ Slow aging } & $-0.11^{*}$ & $9.95^{* *}$ & -0.44 \\
& $(-1.67)$ & $(2.08)$ & $(-0.97)$ \\
\hline \multirow{2}{*}{ Moderate aging } & $-0.14^{* *}$ & $9.79^{* *}$ & -0.19 \\
& $(-2.34)$ & $(2.38)$ & $(-0.74)$ \\
\hline \multirow{2}{*}{ Fast aging } & $-0.18^{* * *}$ & $8.56^{* *}$ & -0.06 \\
& $(-2.77)$ & $(2.35)$ & $(-0.20)$ \\
\hline
\end{tabular}

Note: $* * *, * *$, and $*$ indicate statistical significance at the $1 \%, 5 \%$, and $10 \%$ levels, respectively.

Source: Authors' calculations

\subsection{Actual vs. simulated data}

To compare our empirical evidence and the simulation results, Tables 7-9 present the t-statistics for the panel regression using European data for the same aging groups and the average $t$-statistics for the estimates obtained from simulated data. For the empirical data, the t-statistics are pulled directly from Tables 4-6. For the simulated data, we use the average t-statistics for aging groups according to the value of the aging parameter. For the slow-aging group, we use simulated data with the aging parameter less than or equal to 1.2; for the moderate-aging group, we use simulated data with the aging parameter between 1.2 and 2.4; and for the fastaging group, we use the simulated data with the aging parameter between 2.4 to 3.4. In terms of GDP, GNI, and GNDI, our simulated data appear to be similar to the European data.

Table 7: t-statistics for the capital market channel: Actual vs. simulated data

\begin{tabular}{|c|c|c|c|}
\hline & $\Delta \log \left(g d p_{i, t}\right)$ & $\Delta \log \left(g d p_{i, t}\right) \Delta \log \left(\right.$ old $\left._{i, t}\right)$ & $\Delta \log \left(\right.$ old $\left._{i, t}\right)$ \\
\hline \multicolumn{4}{|l|}{ Slow aging } \\
\hline Actual & 2.22 & -1.32 & -0.26 \\
\hline Simulated & $1.72^{*}$ & 1.16 & 0.05 \\
\hline \multicolumn{4}{|l|}{ Moderate aging } \\
\hline Actual & $1.71^{*}$ & -1.33 & 0.63 \\
\hline Simulated & $6.54^{* * * *}$ & 0.93 & 0.02 \\
\hline \multicolumn{4}{|c|}{ Fast aging } \\
\hline Actual & $3.90^{* * *}$ & $-2.33^{* *}$ & 0.17 \\
\hline Simulated & $11.06^{* * *}$ & 1.04 & 0.05 \\
\hline
\end{tabular}

Note: $* *,{ }^{* *}$, and $*$ indicate statistical significance at the $1 \%, 5 \%$, and $10 \%$ levels, respectively.

Source: Authors' calculations 
Table 7 shows that the t-statistics for income growth are positive and mostly significant for the capital market channel, except for the slow-aging group using the actual data. For the interaction term, however, the t-statistics are mostly insignificant, except for the fast-aging group using actual data, which has a negative estimate. None of the t-statistics for the elderly population growth rate is significant for the actual or simulated data.

For the federal government channel, Table 8 shows that the t-statistics for $\Delta \log \left(g d p_{i, t}\right)$ are positive and significant for both actual and simulated data. For $\Delta \log \left(g d p_{i, t}\right) \Delta \log \left(\operatorname{old}_{i, t}\right)$, the t-statistics obtained from the simulated data are insignificant, whereas those from the actual data are negative and significant for slow- and moderate-aging countries.

Table 8: t-statistics for the federal government channel: Actual vs. simulated data

\begin{tabular}{|c|c|c|c|}
\hline & $\Delta \log \left(g d p_{i, t}\right)$ & $\Delta \log \left(g d p_{i, t}\right) \Delta \log \left(\operatorname{old}_{i, t}\right)$ & $\Delta \log \left(\right.$ old $\left._{i, t}\right)$ \\
\hline Slow aging & $2.74^{* *}$ & $2.25^{* *}$ & $-2.20^{* *}$ \\
\hline Actual & 1.24 & -0.01 & 0.00 \\
\hline Simulated & $3.09^{* * *}$ & $-2.22^{* *}$ & 1.53 \\
\hline Moderate aging & $3.20^{* * *}$ & -0.01 & 0.00 \\
\hline Actual & $3.58^{* * *}$ & -0.91 & -0.01 \\
\hline Simulated & $5.09^{* * *}$ & -0.01 & 0.05 \\
\hline Fast aging &
\end{tabular}

Note: $* * * * *$, and $*$ indicate statistical significance at the $1 \%, 5 \%$, and $10 \%$ levels, respectively. Source: Authors' calculations

As shown in Table 9, the t-statistics obtained from actual and simulated data exhibit similar patterns in their signs and significance levels for the credit market channel and are stable across different aging groups. Economically, the negative t-statistics for $\Delta \log \left(g d p_{i, t}\right)$ suggest that ex-post savings are not supported by this analysis. Further, the t-statistics for the interaction term are positive and significant except for the fast-aging group using simulated data. Table 9 supports the existence of an interaction between elderly population growth and the credit market channel. This evidence suggests that the dis-smoothing via this channel may be more severe with faster aging. Perhaps, increasingly aging populations choose to increase their consumption relative to their disposable income for positive income shocks. 
Table 9: t-statistics for credit market channel: Actual vs. simulated data

\begin{tabular}{|c|c|c|c|}
\hline & $\Delta \log \left(g d p_{i, t}\right)$ & $\Delta \log \left(g d p_{i, t}\right) \Delta \log \left(\operatorname{old}_{i, t}\right)$ & $\Delta \log \left(\right.$ old $\left._{i, t}\right)$ \\
\hline \multicolumn{4}{|l|}{ Slow aging } \\
\hline Actual & $-1.67^{* *}$ & $2.08^{* *}$ & -0.97 \\
\hline Simulated & $-3.60^{* * *}$ & $2.64^{* * *}$ & 0.13 \\
\hline \multicolumn{4}{|l|}{ Moderate aging } \\
\hline Actual & $-2.34^{* *}$ & $2.38^{* *}$ & -0.74 \\
\hline Simulated & $-4.49^{* * *}$ & $2.02^{* *}$ & 0.10 \\
\hline \multicolumn{4}{|l|}{ Fast aging } \\
\hline Actual & $-2.77^{* * *}$ & $2.35^{* *}$ & -0.20 \\
\hline Simulated & $-5.25^{* * *}$ & 1.24 & -0.06 \\
\hline
\end{tabular}

Note: $* * *, * *$, and $*$ indicate statistical significance at the $1 \%, 5 \%$, and $10 \%$ levels, respectively.

Source: Authors' calculations

\section{Results and discussion}

The objective of this study is to test the hypothesis that aging affects risk sharing via the capital market, federal government, and credit market channels. We therefore present results of regressions using simulated and European data. For the simulation, we consider an overlapping-generations model and generate panel data for GDP, GNI, GNDI, and consumption. Using these data, we run the regression in (14) with three dependent variables: $\Delta \log \left(g d p_{i, t}\right)-\Delta \log \left(g n i_{i, t}\right), \Delta \log \left(g n i_{i, t}\right)-$ $\Delta \log \left(\right.$ gndi $\left._{i, t}\right)$, and $\Delta \log \left(\operatorname{gndi}_{i, t}\right)-\Delta \log \left(c_{i, t}\right)$. We note the statistical significance of the interaction term in Equation (14), which is the product of the GDP and elderly population ratio growth rates.

This approach is intended to analytically examine the absorption of an economic shock, $\Delta \log \left(g d p_{i, t}\right)$, by each channel. However, we note that for the simulation of overlapping-generations model, although we follow Asdrubali et al. (1996) in running linear regressions using the simulated data, the relationships between $\Delta \log \left(g d p_{i, t}\right)$ and the shock absorptions are not necessarily linear. Thus, the regression results using the simulated data do not have straightforward interpretations. Bearing that in mind, we discuss the statistical significance of the interaction terms shown in Figures 1, 2, and 3.

Starting with the capital market channel, Figure 1 shows that, in most cases, the interaction terms are not statistically significant. Thus, aging does not significantly affect capital market smoothing. However, the t-statistics are above two when both the aging and risk aversion parameters are large. Extremely large values of the aging parameter imply a faster increase in the elderly population ratio. Thus, 
an increase in country $i$ 's aging parameter increases the ratio of the return on the elderly population's foreign investments to GNI. The difference between GDP and GNI consequently expands, increasing consumption risk sharing via the capital market. An increase in the risk aversion parameter does not itself seem to affect the interaction term for the capital market channel. Rather, the interaction term is more significant for larger risk aversion parameters when the aging parameter is above two. This property is unconventional because risk averse agents generally invest less in risky assets. The aging parameter indicates the speed of the dynamic increase in the elderly population ratio rather than the static elderly population ratio at a particular point in time. Thus, the aging parameter dominates the risk aversion parameter for the capital market channel, emphasizing the role of the foreign risky asset market for risk sharing.

Next, we turn to the federal government channel. In Figure 2, the t-statistics for the interaction term are mostly insignificant. This property implies that aging weakly affects the risk-sharing channel via the federal government. Relatedly, the elderly population ratio, $\mu$, is included in the denominator and the numerator in (9). The denominator differs from the numerator only by the income tax rate, $\tau$. Thus, the influence of the aging parameter on this term in (9) is considerably mitigated for some values of $\tau$.

Lastly, Figure 3 shows that the interaction terms are significant in all cases for the credit market channel and that the t-statistics decrease with the aging parameter. Equivalently, when aging accelerates, the effect of aging on credit market risk sharing weakens. To simplify the discussion, we consider (12). Excluding (1 $A-B$ ) from (12), two main components remain: (i) returns on investment in the previous period, $\mu r_{j} A \nabla_{i, t}$, and (ii) savings from the previous period, $\mu B \nabla_{i, t}$. These components are multiplied by the elderly population ratio, $\mu$, and are therefore increasing in this ratio. The denominator in (12) includes both components, whereas the numerator includes only one of them. Note that the denominator represents per capita consumption and the numerator represents per capita GNDI. Thus, when the elderly population ratio increases, per capita consumption increases to a greater extent than per capita GNDI does. We conjecture that the ratio of GNDI to consumption may decrease when aging is severe. Currently, the gap between GNDI and consumption represents cross-country credit market absorption. Thus, our interpretation of (12) is consistent with Figure 3, which shows that the t-statistics for the interaction term decrease with the aging parameter.

To consider the empirical validity of the simulation results, we run panel regressions using European data. The results of this analysis are somewhat different from those for the simulated data. For the capital market channel, Table 3 shows that the interaction term estimate is negative for the full sample. Thus, aging weakens risk sharing via the capital market. This result contrasts with the positive estimate 
for the simulated data. To check robustness, we perform subsample analyses by dividing the whole sample into three groups: fast-aging, moderate-aging, and slowaging countries. We find consistently negative estimates for the interaction term for all subsamples (Table 4). However, the interaction term estimates are not significant for the slow-aging and moderate-aging subsamples, whereas they are significant for the fast-aging subsample. Thus, only fast aging affects risk sharing via the capital market. This property is consistent with the mostly insignificant interaction terms found for the simulated data.

The results for the federal government channel have unstable signs and significance levels across different subsamples (Table 5). The estimated interaction term is positive and significant for slowly aging countries but negative for moderate- and fast-aging countries. These negative estimates are consistent with the simulated data. However, the negative estimate for the fast-aging subsample is not significant. Thus, the full sample estimate may not be reliable for the federal government channel. Alternatively, the influence of aging on the federal government channel may vary depending on the level of aging.

Turning to the credit market channel, the interaction term estimates are more stable across the subsamples relative to those for the capital market and federal government channels (Table 6). The estimates are consistently positive and significant across subsamples, confirming the results for the full sample. Further, the credit market appears to become a more important risk-sharing channel as aging becomes more severe. This property is supported by the subsample analysis regardless of the level of aging. These results are consistent with the positive and significant estimates using the simulated data.

Finally, we summarize the comparison between the simulated and the European data. We perform a similar subsample analyses for the simulated and European data and compare the results. For more direct comparisons, we present the t-statistics for the interaction term estimates for all three channels. For both datasets, the role of the capital market as a risk-sharing channel is not affected by aging in the slow- and moderate-aging subsamples (Table 7). However, the role of this channel significantly decreases for the fast-aging subsample of the European data. For the federal government channel, the results are less comparable than they are for the capital market channel. For all the subsamples using simulated data, the federal government channel consistently does not contribute to risk sharing (Table 8). In contrast, the federal government plays a significant role in risk sharing for the slowand moderate-aging subsamples of the European data. Lastly, the results for the credit market channel are markedly similar for the simulated and European data (Table 9). Except for the fast-aging subsample using simulated data, we find that the credit market channel contributes more to consumption risk sharing as aging becomes severe. 


\section{Conclusions}

Rapid aging has recently emerged as a central issue in some developed countries. In particular, many European countries face rapid aging. The EU is also believed to facilitate cross-country consumption risk sharing. In this study, we examine the effect of aging on different consumption risk-sharing channels. To do so, we simulate an overlapping-generations economy and compare the simulated data to actual data for the European countries. The simulation results suggest that the effect of aging on consumption risk sharing is more effective for the credit market channel than for the capital market and federal government channels. We find similar results for the empirical data, with some discrepancies, motivating further study on the issue.

\section{References}

Albert, S. M., Duffy, J. (2012) "Differences in Risk Aversion between Young and Older Adults", Neuroscience and Neuroeconomics, Vol. 1, pp. 3-9, doi: 10.2147/ NAN.S27184.

Ambrus, A., Mobius, M., Szeidl, A. (2014) "Consumption risk-sharing in social networks", American Economic Review, 104(1), 149-82, doi: 10.1257/aer.104. 1.149 .

Artige, L., Cavenaile, L., Pestieau, P. (2014) "The Macroeconomics of PAYG Pension Schemes in an Aging Society", mimeo, doi: 10.2139/ssrn.2438689.

Asdrubali, P., Kim, S., (2004) "Dynamic Risksharing in the United States and Europe", Journal of Monetary Economics, Vol. 51, No. 4, pp. 809-836, doi: 10.1016/j.jmoneco.2003.09.002.

Asdrubali, P., Kim, S., (2008a) "Incomplete Intertemporal Consumption Smoothing and Incomplete Risk Sharing", Journal of Money, Credit and Banking, Vol. 40, No. 7, pp. 1521-1531, doi: 10.1111/j.1538-4616.2008.00170.x.

Asdrubali, P., Kim, S., (2008b) "On the Empirics of International Smoothing", Journal of Banking and Finance, Vol. 32, No. 3, pp. 374-381, doi: 10.1016/j. jbankfin.2007.05.005.

Asdrubali, P., Sørensen, B. E., Yosha, O. (1996) "Channels of Interstate Risk Sharing: United States 1963-1990", Quarterly Journal of Economics, Vol. 111, No. 4, pp. 1081-1110, doi: 10.2307/2946708.

Attanasio, O., Davis, S. J. (1996) "Relative Wage Movements and the Distribution of Consumption", Journal of Political Economy, Vol. 104, No. 6, pp. 1227 1262 doi: $10.1086 / 262058$.

Bakshi, G. S., Chen, Z. (1994) "Baby Boom, Population Aging, and Capital Markets", Journal of Business, Vol. 67, No. 2, pp. 165-202, doi: http://www. jstor.org/stable/2353102. 
Becker, S. O., Hoffmann, M. (2006) "Intra-and International Risk-Sharing in the Short Run and the Long Run", European Economic Review, Vol. 50, No. 3, pp. 777-806, doi: 10.1016/j. euroecorev.2004.11.003.

Bellante, D., Green, C. A. (2004) "Relative Risk Aversion among the Elderly", Review of Financial Economics, Vol. 13, No. 3, pp. 269-281, doi: 10.1016/j. rfe.2003.09.010.

Börsch-Supan, A., Härtl, K., Ludwig, A. (2014) "Aging in Europe: Reforms, International Diversification, and Behavioral Reactions", American Economic Review, Vol. 104, No. 5, pp. 224-229, doi: 10.1257/aer.104.5.224.

Bommier, A., Rochet, J. (2005) "Why Do Older People Seem to be Less Risk Averse?", Journal of the European Economic Association, pp. 1-27, https:// www.ifs.org.uk/conferences/rtn_bommier.pdf.

Bovenberg, A. L. (2003) "Financing Retirement in the European Union", International Tax and Public Finance, Vol. 10, No. 6, pp. 713-734, doi: 10.1023/A:1026390122672.

Canova, F., Ravn, M.O. (1996) "International consumption risk sharing", International Economic Review, 573-601.

Catalano, M., Pezzolla, E. (2016) "The Effects of Education and Aging in an OLG Model: Long-run Growth in France, Germany and Italy", Empirica, Vol. 43, No. 4, pp. 757-800, doi: 10.1007/s10663-016-9351-5.

Catalán, M., Magud, N. E. (2017) "A Tradeoff between the Output and Net Foreign Asset Effects of Pension Reform", Open Economies Review, Vol. 28, No. 4, pp. 685-709, doi: 10.1007/s11079-016-9429-5.

Chaulk, B., Johnson, P., Bulcroft, R. (2003) "Effects of Marriage and Children on Financial Risk Tolerance: A Synthesis of Family Development and Prospect Theory", Journal of Family and Economic Issues, Vol. 24, No. 3, pp. 257-279, doi: 10.1023/A:1025495221519.

Chiappori, P. A., Samphantharak, K., Schulhofer-Wohl, S., Townsend, R. M (2014) "Heterogeneity and risk sharing in village economies", Quantitative Economics, Vol. 5, No. 1, 1-27, doi: 10.3982/QE131.

Cipriani, G. P. (2014) "Population Aging and PAYG Pensions in the OLG Model", Journal of Population Economics, Vol. 27, No. 1, pp. 251-256, doi: 10.1007/ s00148-013-0465-9.

Cochrane, J. H. (1991) “A Simple Test of Consumption Insurance", Journal of Political Economics, Vol. 99, No. 5, pp. 957-976, doi: 10.1086/261785.

Crucini, M. J. (1999) "On International and National Dimensions of Risk Sharing", Review of Economics and Statistics, Vol. 81, No. 1, pp. 73-84, doi: https://doi. org/10.1162/003465399767923836.

Cuaresma, J. C., Loichinger, E., Vincelette, G. A. (2016) “Aging and Income Convergence in Europe: A Survey of the Literature and Insights from a 
Demographic Projection Exercise", Economic Systems, Vol. 40, No. 1, pp. 4-17, doi: 10.1016/j.ecosys.2015.07.003.

D’Amato, M., Galasso, V. (2010) "Political Intergenerational Risk Sharing", Journal of Public Economics, Vol. 94, No. 9, pp. 628-637, doi: 10.1016/j. jpubeco.2010.05.004.

Davis, S., Willen, P. (2000) "Risky labor income and portfolio choice", Manuscript, Business School, U. of Chicago.

De La Croix, D., Pierrard, O., Sneessens, H. R. (2013) "Aging and Pensions in General Equilibrium: Labor Market Imperfections Matter", Journal of Economic Dynamics and Control, Vol. 37, No. 1, 104-124, doi: 10.1016/j. jedc.2012.06.011.

De Meijer, C., Wouterse, B., Polder, J., Koopmanschap, M. (2013) "The effect of population aging on health expenditure growth: A critical review", European Journal of Ageing, Vol. 10, No. 4, pp. 353-361, doi: 10.1007/s10433-013-0280-x.

Decressin, J. (2002) "Regional Income Redistribution and Risk Sharing: How Does Italy Compare in Europe?", Journal of Public Economics, Vol. 86, No. 2, pp. 287-306, doi: 10.1016/S0047-2727(01)00150-5.

Dedry, A., Onder, H., Pestieau, P. (2017) "Aging, Social Security Design, and Capital Accumulation", Journal of the Economics of Ageing, Vol. 9, pp. 145-155, doi: 10.1016/j.jeoa.2016.10.003.

Dynarski, S., Gruber, J (1997). "Can Families Smooth Variable Earnings?", Brookings Papers On Economic Activity, 1997, No. 1, pp. 229-303, doi: https:// EconPapers.repec.org/RePEc:bin:bpeajo:v:28:y:1997:i:1997-1:p:229-303.

Ferrari, A., Picco, A. R. (2016) "International Risk Sharing in the EMU”, European Stability Mechanism, mimeo, doi: 10.2139/ssrn.3013105.

Gerrans, P., Clark-Murphy, M., Speelman, C. (2010) "Asset Allocation and Age Effects in Retirement Savings Choices", Accounting and Finance, Vol. 50, No. 2, pp. 301-319, doi: 10.1111/j.1467-629X.2009.00330.x.

Hallahan, T., Faff, R., McKenzie, M. (2003) "An Exploratory Investigation of the Relation Between Risk Tolerance Scores and Demographic Characteristics", Journal of Multinational Financial Management, Vol. 13, No. 4-5, pp. 483502, doi: 10.1016/S1042-444X(03)00022-7.

Hamman, M.K. et al. (2016). "Peer Effects and Retirement Decisions: Evidence from Pension Reform in Germany", NBER Workshop on Ageing and Health, mimeo.

Hartley, R., Lanot, G., and Walker, I. (2014) "Who really wants to be a millionaire Estimates of risk aversion from gameshow data", Journal of Applied Econometrics, Vol. 29, No. 6, pp. 861-879, doi: 10.1002/jae.2353.

Hayashi, F., Altonji, J., Kotlikoff, L. (1996) "Risk-Sharing between and within Families”, Econometrica, Vol. 64, No. 2, pp. 261-294, doi: 10.2307/2171783. 
Hepp, R., von Hagen, J. (2012) "Interstate Risk Sharing in Germany: 1970-2006", Oxford Economic Papers, Vol. 65, No. 1, pp. 1-24, doi: https://doi.org/10.1093/ oep/gps018.

Hollanders, D. A. (2012) “The Effect of Aging on Pensions", Tilburg University, doi: https://pure.uvt.nl/ws/portalfiles/portal/1435386/ProefschriftHollanders 20120413.pdf.

Jianakoplos, N. A., Bernasek, A. (2006) "Financial Risk Taking by Age and Birth Cohort", Southern Economic Journal, Vol. 72, No. 4, pp. 981-1001, doi: 10.2307/ 20111864.

Kim, S., Kim, S. H., Wang, Y. (2006) "Financial Integration and Consumption Risk Sharing in East Asia", Japan and the World Economy, Vol. 18, No. 2, 143-157, doi: 10.1016/j.japwor.2004.10.001.

Kolasa, A., Rubaszek, M. (2016) "The Effect of Ageing on the European Economies in a Life-Cycle Model", Economic Modelling, Vol. 52, No. 1, pp. 50-57, doi: 10.1016/j.econmod.2015.06.020.

Kruse, A. (2002) "Ageing Populations and Intergenerational Risk-Sharing in PAYG Pension Schemes", Working paper, Department of Economics, Lund University, doi: http://project.nek.lu.se/publications/workpap/Papers/WP02_18.pdf.

Börsch-Supan, A.Ludwig, A., Winter, J. (2002) "Aging and International Capital Flows", Munich Center for the Economics of Aging (MEA) at the Max Planck Institute for Social Law and Social Policy, doi: http://mea.mpisoc.mpg.de/ uploads/user_mea_discussionpapers/dp10.pdf.

Mace, B. J. (1999) "Full Insurance in the Presence of Aggregate Uncertainty", Journal of Political Economy, Vol. 99, No. 5, pp. 928-956, doi: 10.1086/261784.

Mélitz, J., Zumer, F. (1999) "Interregional and International Risk-sharing and Lessons for EMU", Carnegie-Rochester Conference Series on Public Policy, Vol. 51, North-Holland, doi: 10.1016/S0167-2231(00)00008-7.

Meyer, J. (2010) "Representing risk preferences in expected utility based decision models", Annals of Operations Research, Vol. 176, No. 1, pp. 179-190.

Palsson, A.-M. (1996) "Does the Degree of Relative Risk Aversion Vary with Household Characteristics?", Journal of Economic Psychology, Vol. 17, No. 6, pp. 771-787, doi: 10.1016/S0167-4870(96)00039-6.

Park, Y. J., Song, J. (2009) "An Empirical Study on the Consumption Risk Sharing across the EU Regions", International Area Studies Review, Vol. 13, No. 2, pp. 89-115, doi: http://www.riss.kr/link?id=A99894808.

Park, S., Song, J. (2018) "Revisiting Full Insurance Test under Risk Aversion Heterogeneity", mimeo.

Poterba, J. M. (2004) "Impact of Population Aging on Financial Markets in Developed Countries", Federal Reserve Bank of Kansas City Economic Review, Vol. 89, No. 4, pp. 43-53, doi: https://search.proquest.com/docview/218423888 ?accountid=10113. 
Poterba, J. M. (2014) "Retirement Security in an Aging Population", American Economic Review, Vol. 104, No. 5, pp. 1-30, doi: 10.1257/aer.104.5.1.

Schröder, H., Flynn, M., Klassen, T., Antoniou, A. S., Park, M. J. (2016).“Population Aging and Labor Market Policy in Germany, the United Kingdom, Japan, and the Republic of Korea: The Effects of Institutional Context on Old Age Employment", In The Aging Workforce Handbook: Individual, Organizational, and Societal Challenges (pp. 109-134). Emerald Group Publishing Limited, doi: https://doi.org/10.1108/978-1-78635-448-820161005.

Schulhofer-Wohl, S. (2011) "Heterogeneity and Tests of Risk Sharing", Journal of Political Economy, Vol. 119, No. 5, pp. 925-958, doi: 10.1086/662720.

Social Protection Committee. (2012) "Pension Adequacy in the European Union 2010-2050", Vol. 7, doi: 10.2767/77325.

Song, J. (2011) "The Relation between the Income Smoothing and the Consumption Smoothing: The EU Case", International Area Studies Review, Vol. 15, No. 3, pp. 191-213, doi: http://www.riss.kr/link?id=A82771147.

Song, J. (2012) "Demographic Effects on the Consumption Risk-sharing: The 50 States of the U.S. for 80's", Proceeding of the 87th Annual Western Economic Association Conference.

Song, J. (2015) "Testing Consumption Risk-sharing under Heterogeneous Riskaversion", Journal of Korean Economic Studies, Vol. 33, No. 1, pp. 5-37, doi: http://www.riss.kr/link?id=A100470448.

Sørensen, B. E., Yosha, O. (1998) "International Risk Sharing and European Monetary Unification", Journal of International Economics, Vol. 45, No. 2, pp. 211-238, doi: 10.1016/S0022-1996(98)00033-6.

Storesletten, K., Telmer, C. I., Yaron, A. (2004) "Consumption and Risk Sharing over the Life Cycle", Journal of Monetary Economics, Vol. 51, No. 3, pp. 609633, doi: 10.1016/j.jmoneco.2003.06.005.

Stulz, R.M. (1981) "On the effects of barriers to international investment", Journal of Finance, Vol. 36, No. 4, pp. 923-934.

Sørensen, B. E., Wu, Y-. T., Yosha, O., Zhu, (2007) "Home Bias and International Risk Sharing: Twin Puzzles Separated at Birth", Journal of International Money and Finance, Vol. 26, No. 4, pp. 587-605, 10.1016/j.jimonfin.2007.03.005.

Supan, A. (2017) "Aging and Pension Reform: Extending the Retirement Age and Human Capital Formation", Journal of Pension Economics and Finance, Vol. 16, No. 1, pp. 81-107, doi: 10.1017/S1474747215000086.

Tabata, K. (2015) "Population Aging and Growth: The Effect of Pay-as-you-go Pension Reform", FinanzArchiv: Public Finance Analysis, Vol. 71, No. 3, 385406, doi: 10.1628/001522115X14385891669698.

Torben, M. A. (2014) "Intergenerational Redistribution and Risk Sharing with Changing Longevity", Journal of Economics, Vol. 111, No. 1, pp. 1-27, doi: 10.1007/s00712-013-0336-6. 
Tyrowicz, J., Makarski, K., Bielecki, M. (2016) "Reforming Retirement Age in DB and DC Pension Systems in an Aging OLG Economy with Heterogenous Agents", IZA Journal of Labor Policy, Vol. 5, No. 8, pp. 1-36, doi: 10.1186/ s40173-016-0067-8.

Verbič, M., Rok, S. (2014) "Aging Population and Public Pensions: Theory and Macroeconometric Evidence”, Panoeconomicus, Vol. 61 No. 3, pp. 289-316, doi: 10.2298/PAN1403289V.

von Wyl, V., Beck, K. (2014) "Risk Adjustment in Aging Societies", Health Economics Review, Vol. 4, No. 7, pp. 1-14, doi: 10.1186/s13561-014-0007-5.

Wallach, M. M., Kogan, N. (1961) "Aspects of Judgment and Decision Making: Interrelationships and Changes with Age", Behavioral Science, Vol. 6, No. 1, pp. 23-26, doi: http://onlinelibrary.wiley.com/doi/10.1002/bs.3830060104/full.

Wang, H., Hanna, S. (1997) “Does Risk Tolerance Decrease with Age?”, Journal of Financial Counseling and Planning, Vol. 8, No. 2, pp. 27-31, doi: 10.2139/ ssrn.95489. 
Utjecaj starenja na kanale potrošnje uz podjelu rizika za europske zemlje ${ }^{1}$

\author{
Jeongseok Song ${ }^{2}$, Doojin Ryu ${ }^{3}$
}

\begin{abstract}
Sažetak
Ovaj rad provjerava hipotezu o utjecaju starenja na podjelu rizika putem različitih kanala: tržišta kapitala, kanala središnje države i kreditnog tržišta. Primjenjuje se metoda dekompozicije za obradu simuliranih podataka i podataka za zemlje Europske unije. Za dobivanje simuliranih podataka primijenili smo jednostavan model preklapajućih generacija i generirali podatke teoretski prikladne za model. U empirijskoj analizi koristili smo EU podatke uz primjenu modela dekompozicije varijance. Ovim istraživanjem potvrđen je značajan utjecaj starenja na potrošnju uz podjelu rizika putem kanala kreditnog tržišta, dok drugi kanali pokazuju neke mješovite rezultate. S umjerenom rezervom, naši empirijski rezultati za europske zemlje u skladu su s rezultatima procjene izvedenim iz simuliranih podataka.
\end{abstract}

Ključne riječi: Europske zemlje, starenje, potrošnja uz podjelu rizika, ekonomska integracija, , dekompozicija varijance

JEL klasifikacija: F15, F36, G20, H7

1 Zahvaljujemo se glavnom uredniku i anonimnim recenzentima na korisnim komentarima. Ranija verzija rada ("Demographic Effects on the Consumption Risk-sharing") prezentirana je na konferenciji 87th Annual Western Economic Association Conference.

2 Izvanredni profesor, Chung-Ang University, College of Business and Economics, School of Economics, 84, Heukseok-ro, Dongjak-gu, Seoul, 06974, Republika Koreja. Znanstveni interes: otvorena makroekonomija, međunarodne financije, primijenjena ekonometrija. Tel.: +822820 5640.Fax:+8223280 5582.E-mail: jssong@cau.ac.kr.

3 Redoviti profesor, Sungkyunkwan University, College of Economics, 25-2, Sungkyunkwan-ro, Jongno-gu, Seoul 03063, Republika Koreja. Znanstveni interes: cijena imovine, financijska ekonomija, tržišna mikrostruktura. Tel.: +82 2760 0429. Fax: +82 2760 0950. E-mail: sharpjin@skku.edu. Osobna web stranica: https://sites.google.com/site/doojinryu/home/info (osoba za kontakt). 


\section{Appendix}

In this appendix, we provide a mathematical explanation for the following firstorder conditions:

$\max \frac{1}{1-\sigma}\left(c_{i, t}^{y}\right)^{1-\sigma}+\beta E_{t}\left[\frac{1}{1-\sigma}\left(c_{i, t+1}^{o}\right)^{1-\sigma}\right]$

$$
\begin{array}{cc}
\text { s.t. } & c_{i, t}^{y}+a_{i, t}+s_{i, t}=(1-\tau) y_{i, t} \\
& c_{i, t+1}^{o}=a_{i, t} r_{i, t+1}+s_{i, t}
\end{array}
$$

For notational convenience, we drop the subscript $i$ below. We first substitute the constraints into the utility function and assume that the risky asset returns follow a binomial distribution such that higher, $r_{H}$, and lower, $r_{L}$, returns occur with the same probability, 0.5 .

(i) The first-order condition with respect to $a_{t}$ is:

$$
\begin{aligned}
& \frac{d u}{d a_{t}}=\left[(1-\tau) y_{t}-a_{t}-s_{t}\right]^{-\sigma}(-1)+\left(\frac{\beta}{2}\right)\left(a_{t} r_{H}+s_{t}\right)^{-\sigma} r_{H}+ \\
& +\left(\frac{\beta}{2}\right)\left(a_{t} r_{L}+s_{t}\right)^{-\sigma} r_{L}=0
\end{aligned}
$$

(ii) The first-order condition with respect to $s_{t}$ is:

$$
\frac{d u}{d s_{t}}=\left[(1-\tau) y_{t}-a_{t}-s_{t}\right]^{-\sigma}(-1)+\left(\frac{\beta}{2}\right)\left(a_{t} r_{H}+s_{t}\right)^{-\sigma}+\left(\frac{\beta}{2}\right)\left(a_{t} r_{L}+s_{t}\right)^{-\sigma}=0
$$

As mentioned in section 3.2, we denote the ratios of the optimal investment and savings to the disposable endowment by $A$ and $B$, respectively. Thus, the optimal levels of investment and savings equal $A(1-\tau) y_{t}$ and $B(1-\tau) y_{t}$, respectively. We define $D$ as satisfying $B=A D$. Together with the operational definitions of $A, B$, and $D$, we combine the first-order conditions in (i) and (ii). Then, we obtain Equations (4) and (5) in section 3.2. 